\title{
Pedagógushallgatók digitális kompetenciáinak fejlesztési lehetőségei
}

\author{
Turzó-Sovák Nikolett \\ ELTE TÓK Digitális Pedagógiai Tanszék
}

\begin{abstract}
Absztrakt
A 21. századi oktatás egyik kihívása a digitális eszközök hatékony alkalmazása az oktatási folyamatban. Ennek elengedhetetlen feltétele a digitális kompetenciák fejlesztése. A fogalom meghatározása az elmúlt évtizedekben bővült, így ma már nem csak a digitális eszközök használatát értjük alatta, sokkal inkább tudáselemekből, készségekből és attitűdből szövődő rendszert. Az Európai Bizottság DigComp digitális keret megalkotásával 5 kompetenciaterület alatt fogalmazta meg azt a 21 irányadó részkompetenciát, amelyekkel az egyén versenyképességét növelni tudja a munkaerőpiacon. A keret által meghatározott részkompetenciák irányadók a felsőoktatásban folyó pedagógusképzés számára is. Az ELTE Tanító- és Óvóképző Kar, Digitális Pedagógiai Tanszéke a digitális kompetenciát meghatározó európai szabványkeretnek megfelelően szervezett kurzusokkal készíti fel hallgatóit a pedagógiai pályára.
\end{abstract}

Kulcsszavak: digitális kompetencia, pedagógusképzés, kompetenciarendszerek, kompetenciafejlesztés

A versenyképesség egyik meghatározó tényezője ma már megkérdőjelezhetetlenül az egyén adott területre jellemző digitális felkészültsége. Az oktatásban egyre inkább jelen levő IKT-eszközök megjelenése nélkülözhetetlenné teszi, hogy a gyakorló pedagógusok is rendelkezzenek az IKT-eszközök hatékony használatához szükséges megfelelő ismerettel, tudással, készséggel. Az oktatásban zajló innováció és tantervi átalakulás megköveteli, hogy felkészült, az újdonságokra nyitott tanítók, óvodapedagógusok és kisgyermeknevelők kerüljenek a munkaerőpiacra.

Jelen tanulmány célja, hogy a fogalmi áttekintés után bemutassa az oktatáspolitika által megalkotott digitáliskompetencia-rendszereket és azt, hogy ennek megfelelően hogyan készítjük fel pedagógushallgatóinkat a munkavállalás kihívásaira.

A pedagógusképzésben figyelmünk a tárgyi tudás kialakításán túl, a hallgatók digitális eszközök használatával kapcsolatos attitűdformálására kon- 
centrálódik. Nem elég csupán megismertetni a hallgatókkal az eszközökben rejlő lehetőségeket, azt is meg kell mutatnunk nekik, hogy a pedagógiai folyamat mely pontján hasznos és érdemes alkalmazni azokat.

A kompetencia fogalmát a neveléstudomány több oldalról közelíti meg, foglalja elméleti keretbe. Nagy József (2002) személyiség szempontjából történő megközelítésére szerint a kompetencia az a belső feltétel, a feladat elvégzésének teljesítésre való alkalmasság, mely elősegíti az egyén és a környezet közötti kapcsolat hatékonyságát. A környezet és oktatás személyiségre való hatását vizsgálva három fő kategóriát nevez meg: személyes (perszonális), kognitív, és szociális terület melyek mindegyike további részkompetenciákat tartalmaz.

A társadalmi hasznosithatóság megközelítés szerint a kompetencia az egyéni cselekvés eredménye, vagyis „teljesítményképes” tudás (Kárpáti \& Lakatos Török, 2009, p. 227). Csapó (2002) a kompetencia fogalmát a müveltség és a szakértelem fogalmától különíti el. Elmélete szerint az egyénben kialakult kompetencia, mely készségekből, képességekből, tudásból, szakértelemből szerveződik, sokszínű és változatos mintát mutathat.

Lakatosné Török és Kárpáti 2009-es tanulmányában bemutatja, hogy az Európai Unió oktatáspolitikai szakértői nem egyéni tulajdonságként, hanem összetett rendszerként értelmezik a kompetencia fogalmát. Megtudhatjuk, hogy a DeSeCo program (Defining and Selecting Key Competencies) keretében a kulcskompetenciák, és a hozzájuk kapcsolódó területek, elvárások azok funkciója alapján kerültek meghatározásra. A megalkotott kompetenciaterületek adják azt a szabványkeretet, melyhez igazodva készülnek az oktatási szakértők által készült curriculumok, tantervek.

Hazánkban, a 2020-ban megjelent Nemzeti alaptanterv az Európai Unió által megfogalmazott alapértékeket és irányelveket alapul véve a következő tanuláson átívelő hét kulcskompetenciát határozta meg: 1 . A tanulás kompetenciái, 2. A kommunikációs kompetenciák, 3. A digitális kompetenciák, 4. A matematikai, gondolkodási kompetenciák, 5. A személyes és társas kapcsolati kompetenciák, 6. A kreativitás, a kreatív alkotás, önkifejezés és kulturális tudatosság kompetenciái, 7. Munkavállalói, innovációs és vállalkozói kompetenciák (NAT, 2020, p. 297). Ezek a kompetenciák a tantárgyakon átívelő fejlesztendő területként jelennek meg. Egyes tantárgyi követelményeknél láthatjuk, hogy mely digitális tartalom, eszköz segítségével szükséges a digitális kompetenciát fejleszteni.

A digitális kompetencia meghatározása a szakirodalomban igen széles skálán mozog. A fogalom a 2000-es évek elején jelent meg az élethosszig tartó tanulás (life-long learning) egyik előfeltételeként (Jorgen, 2017). Nyers értelmezésként azt mondhatnánk, hogy a digitális kompetencia az IKT-eszközök használatának képessége. Egy másik megközelítés szerint a digitális kompetencia nem más, mint bizonyos eszközök és szoftverek alkalmazásának képessége (Jorgen, 2017). Azonban ennél sokkal összetettebb jelenségről van szó. A digitális kompetencia a technológiai fejlődés során létrejött komp- 
lex egység, amely tudás-képesség-attitűd fogalmak mentén alakul ki. Tágabb megfogalmazásokban kompetencia-részterületek kerülnek meghatározásra. Sabaliauskas (2006) szerint a következők határozzák meg a digitális kompetenciát: alap IKT-kompetencia, IKT használatának irányelveire vonatkozó kompetencia, etikus használat kompetencia, IKT-eszközök használata a pedagógiai folyamatban kompetencia. Âtfogó, tág értelmezés szerint a digitális kompetencia magában hordozza az informatikai eszközök segítségével történő problémamegoldást, az információkeresést, annak szűrését, értékelését; a digitális környezetben történő kommunikációt, az online térben történő feladatmegoldó együttmüködést, a digitális biztonságot és a digitális tartalom létrehozását is (Lénárd, 2019). Széles szakmai körben elfogadott nézet szerint a következő öt terület öleli fel a digitális kompetencia fogalmát: 1. információ- és adatkezelés, 2 . kommunikáció és együttmüködés, 3. digitális tartalmak létrehozása, 4. biztonság, 5. problémamegoldás (Halász, 2019).

Ala-Mutka (2011) a szakirodalomban megjelent meghatározásokat öszszevetve alkotta meg a következő ábrát, amely szemléletesen mutatja be, a digitális kompetencia részkompetenciáit. (1. ábra) A magas szintü digitális kompetenciát nem csupán az eszközök használata, a kognitív elemek, hanem az egyént átszövő attitűdök is meghatározzák.

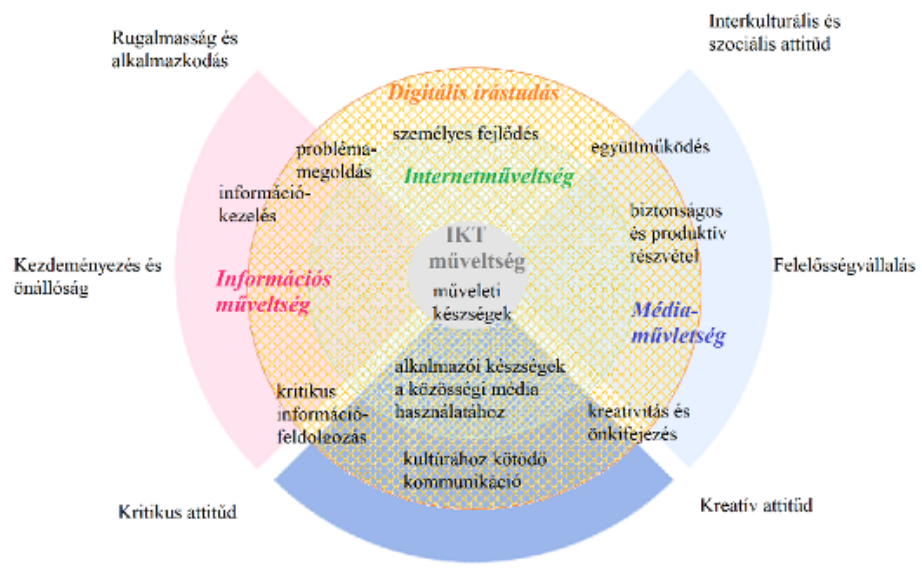

1. ábra

21. századi digitáliskompetencia-térkép (Ala-Mutka alapján, 2011, p. 44).

A neveléstudomány kutatóit régóta foglalkoztatja a kérdés, mely kompetenciák szükségesek egy pedagógus sikeres és hatékony munkájához. Nem vitatható el, hogy a digitális kompetencia az egyik alappillére a sikernek. 
A pedagógusok speciális helyzetben vannak a digitális kompetencia tekintetében. A digitális kompetencia eddigi értelmezése mellett szükségük van még didaktikai, módszertani tudásra, ismeretre is ahhoz, hogy a tanulási-tanítási folyamatban hatékonyan tudják használni a digitális eszközök adta lehetőségeket. Krumsvik szerint akkor megfelelő a pedagógus digitális kompetenciája, ha az IKT-eszközöket megfelelő pedagógiai-didaktikai megfontolás mellett használja, tudatosítva a tanulási stratégiákra gyakorolt hatását, figyelembe véve a tanulók digitális képzettségét (Krumsvik, 2011). A felvázolt modell a pedagógus tudatossága és gyakorlati jártassága alapján határozza meg a tantermi környezetben hatékony, a pedagógusok számára szükséges digitális kompetenciát. (2. ábra) A négy, egymásra épülő komponens a következőket tartalmazza:

- Alapvető digitális készségek: eléréséhez a digitális eszközöknek „többé-kevésbé átláthatónak kell lennie" (Jurgen, 2017, p. 46). A pedagógusoknak tudni kell, hogy „hogyan lehet használni” bizonyos eszközöket (Krumsvik, 2011, p. 46).

- Az IKT-kompetencia didaktikai aspektusa arra utal, hogy a pedagógus a tananyag feldolgozása közben képes az IKT-eszközöket kompetenciaalapú célok elérése érdekében használni.

- Tanulási stratégiák komponens metaperspektívát feltételez a megelőző egységekből. A pedagógus számára az új tanulási környezet új lehetőségeket teremt a tanulásszervezésben.

- „Digital Bildung” komponens több a digitális oktatásnál. Egy összetett digitális formációt jelent, ahol a megváltozott oktatási folyamatnak együtt részese a tanár, a diák és a szülő. Arra fókuszál, hogy a társadalom digitalizálása hogyan befolyásolja a tanulók részvételét a digitális oktatásban, digitális világban. 


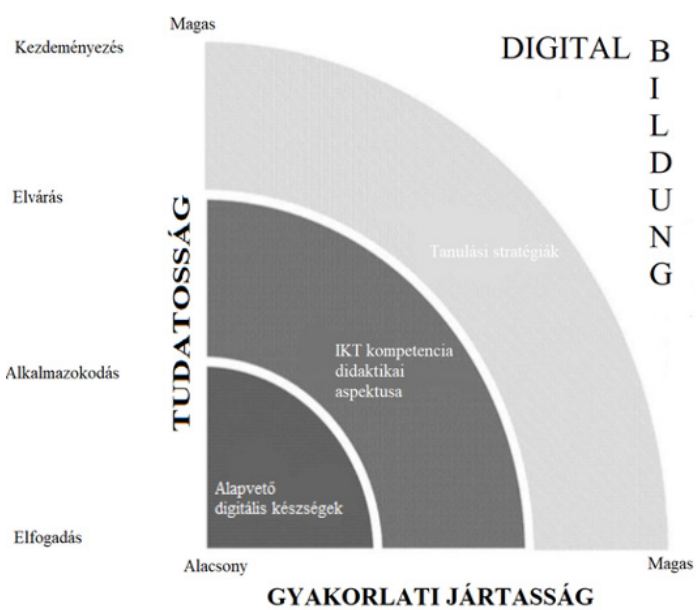

2. ábra

A pedagógusok digitális kompetenciájának modellje Krumsvik alapján (2011, p. 46).

Az eddig áttekintett elméleti meghatározások alapján egyértelműen kirajzolódik, hogy a digitális kompetencia részeinek mértékét nem lehet egyazon módszerrel, mérőeszközzel vizsgálni. A mérhetőség pedig elengedhetetlen feltétel ahhoz, hogy értékelést, majd fejlesztést lehessen a területen végezni.

A feltételrendszer szükségességét felismerve 2005-ben átfogó kutatások kezdődtek, melynek eredményeként 2013-ban az Európai Bizottság szakemberei megalkották a DigComp (Digital Competence Framework for Citizens) digitáliskompetencia-keretet, amely két fö részből tevődik össze (Ferrari, 2013). Egyrészt a dokumentum tartalmazza az öt kategóriába sorolt 21 digitális kompetenciát (3. ábra), másrészt tartalmaz egy önértékelő eszközt, amely a legfrissebb, 2018-ban megjelent módosítása eredményeképpen az eredeti három készségszintet nyolc szintre bővítette (alapszinttől a mesterszintig), és gyakorlati példákkal egészítette ki. A dokumentum pontosan meghatározza a készségszintekhez szükséges ismereteket, kognitív részterületeket.

A keretrendszer két eszköze lehetőséget ad az oktatáspolitikának, tanulásszervezésnek, valamint az állampolgároknak arra, hogy kövessék digitális kompetenciájuk szintjét, célokat tüzzenek ki, megvalósítási tervet készítsenek. Emellett lehetőséget ad a nemzeteknek saját oktatáspolitikai keretrendszer megalkotására (Racskó, 2017). 


\section{DigComp digitáliskompetencia-keret (2013)}

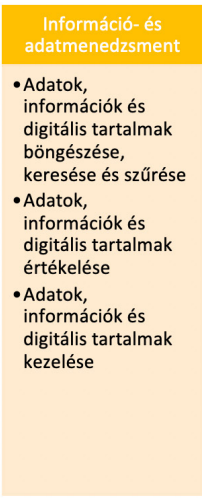

Kommunikáció és
egyuittmuúkódés
- Interakció digitális
technológiákon
keresztül
- Megosztás digitális
technológiák
segítségével
- Együttmúködés
digitális
technológiák
segítségével
-Állampolgári
részvétel digitális
technológiák
segítségével
- Netikett
-A digitális
személyazonosság
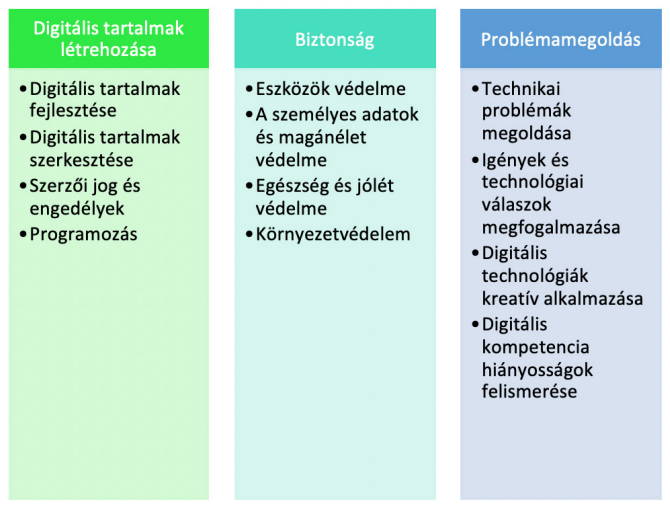

3. ábra

A digitális kompetencia értelmezésének európai keretrendszere Ferrari alapján (2013, p. 5-6.).

Hazánkban az Infokommunikációs Egységes Referenciakeret (IKER) 2015-2016-ban került kidolgozásra. A megalkotók azzal a céllal keltették életre a referenciakeretet, hogy a nemzetközi gyakorlathoz hasonlóan hazánkban is létezzen egy olyan eszköz, amely képes a digitális kompetenciákat a hazai viszonyoknak megfelelően mérni és támogatni. A referenciakeret öt fö területet határoz meg, melyhez négy szintet kapcsol: 1 . Az információ gyűjtése; felhasználása, tárolása, 2. digitális, internetalapú kommunikáció, 3 . digitális tartalmak létrehozása, 4. problémamegoldás, gyakorlati alkalmazás, 5. IKT-biztonság.

Egy 2018-ban történt felmérés alapján, melynek célja a pedagógus munkakörben dolgozók digitális kompetenciájának feltérképezése volt, a DigComp keretrendszer öt kompetenciaterületét alapul véve, a kutatásban résztvevők pedagógusokat a DigComp eredeti három alapkategóriájába sorolták be : alap, közepes, haladó. A felmérés eredményként azt kapták, hogy a leginkább birtokolt kompetenciaterület a technológia ismerete, a legkevésbé pedig a digitális identitás kompetenciái (Eszenyiné, 2018).

A pedagógusok digitális kompetenciájának kialakítása nem fejeződik be egyetemi tanulmányaik végeztével. Mint ahogy a közoktatásban, úgy a felsőoktatásban is nézőpontváltásra van szükség. Az ELTE Tanító- és Ovóképző Karon a pedagógushallgatókat (tanítók, óvodapedagógusok és kisgyermeknevelő szakos hallgatók) a kompetenciarendszerek által vázolt részkompe- 
tenciák mentén készítjük fel a pedagógiai munkára. Célkitűzésünk, hogy a pedagógusok eszköztárát színesítő lehetőségeket gyakorlati példákon keresztül, módszertani segédlettel közvetítsük.

Nagy hangsúlyt fektetünk arra, hogy a digitális eszközök használatával szemben pozitív attitüdöt és rugalmasságot alakítsunk ki hallgatóinkban. A tudáselemeknek, amelyeket átadunk, a változó digitális világban néhány év múlva már újabb verziója lesz elérhető. Ezért fontos, hogy kialakuljon a hallgatókban az önfejlesztés igénye (Duchon, 2016), az igény, hogy vágyjanak az újabb eszközök megismerésére.

A közös munka során fókuszba helyezzük a pedagógusszerep megváltozott voltát. Ma már nem a pedagógus minden tudás forrása, hanem irányító személy (Müller, 2016), aki jól előkészített útvonalon hagyja, hogy a tanulók maguk fedezzék fel az ismereteket. A kurzusokon facilitátori szerepkört segítő digitális tartalmakat hozunk létre, úgy, hogy maguk a hallgatók is megtapasztalják milyen érzés a felfedezési folyamat részesének lenni.

Az elsajátítandó tananyag a DigComp keretrendszerben meghatározott 21 részkompetenciára épül. A tananyag a hallgatók szakterületét figyelembe véve más területre fókuszál. Az ismeretek átadását követően a munkát a szemináriumon jellemzően saját digitális tartalom létrehozása jelenti. Legyen ez az adatok kezelése vagy egy rövidfilm készítése. Ezek a feladatok mindig valamilyen téma-, tananyag-feldolgozási segédletként a hallgató birtokában maradnak. Ezeket a tartalmakat a hallgatók a saját online felületükön helyezik el, így a kurzusok elvégzésével egyfajta digitális portfólióval rendelkeznek, amelyet későbbi gyakorlatuk során kiinduló tudásbázisként használhatnak fel.

$A z$ információ- és adatmenedzsment kompetencia kialakítása során az etikus adatfelhasználással és kritikus szelektálással fejlesztjük a digitális tartalmak szürésének, értékelésének és kezelésének kompetenciáját. A hallgatók számára az online feladatgyüjtemények (például Okos Doboz) megismerésével reflektorfénybe helyezzük, hogy melyek azok a biztosítékok, amelyek a lektoráltságot, minőségi feladatbázist jellemzik.

A kommunikáció és együttmüködés kompetenciaterület fejlesztésére szolgálnak például azok a gyakorlatok, melyek során kollaboratív munkában ismerkednek meg a hallgatók a felhőalapú szolgáltatásokkal (Google Drive, Microsoft OneDirve), és az azokban rejlő lehetőségekkel. Digitális tartalom készül kérdőív vagy prezentáció szerkesztéséből. Az elkészült tartalmakat különböző hozzáférési engedéllyel osztjuk meg. A hallgatók a kurzus keretein belül megismerkednek az online tesztekkel (Redmenta, Kahoot stb.) is.

A digitális tartalmak létrehozása kompetenciaterület részkompetenciáit az elérhető táblaszoftverek (Smart), feladatgenerátor.oldalak (LearningApps, Wordwall stb.) használatával mélyítjük el. A kurzusok során a hallgatók megismerkednek azokkal az interneten fellelhető oldalakkal, ahol az oktatási tevékenységhez segédanyagot készíthetnek (szófelhő, gondolattérkép, puzzle, játékkészítő oldalak, keresztrejtvény-készítő oldalak stb.). Emellett egy-egy 
óvodai vagy iskolai témakör feldolgozásával kép-, hang- és videó szerkesztéis tevékenységgel alkotó munkát végzünk. A hallgatók a robotika és a kódolás kisgyermekkorban való sajátosságaival, ismereteivel is megismerkednek. Amellett, hogy az új NAT részévé vált a robotika és kódolás tananyag, a „tanulók problémamegoldó képessége, algoritmikus gondolkodása fejleszthető, aktivitásuk fokozható" (Vetési, 2018, p. 10).

A biztonság kompetenciaterület tekintetében többek között a személyes adatok védelmi beállításait vesszük górcső alá. A digitális lábnyom fogalmán keresztül hangsúlyt helyezünk a cyberbullying jelenségre. Különös tekintettel vagyunk a korosztályok számára ajánlott digitálistartalom-fogyasztás mértékére, ezzel is erősítve az egészség és jólét védelmét.

A problémamegoldás kompetenciaterület során a létrehozott tartalmakat az oktatási folyamat egy-egy pontján (esetleg tanítási gyakorlat során) helyezzük el. Ez a terület egyfajta önreflektálásra ad lehetőséget, fejlesztendő területek, hiányosságok észrevételét öleli fel. Az attitüdformálás során a hallgatók egyre bátrabban kérnek segítséget, és nyitnak az újdonságok felé.

A kurzusok követelményei pedig a DigComp keretrendszerben megfogalmazott alap-, közép- és mesterszint alapján vannak meghatározva. A követelményrendszer megalkotásakor figyelembe kellett vennünk, hogy a hallgatók a belépéskor igen eltérő digitális jártassággal rendelkeznek. A szemináriumi foglalkozások során igyekszünk ezeket a különbségeket közelebb hozni egymáshoz.

\section{Összegzés}

Az elmúlt hónapokban láthattuk, hogy a 21. századi oktatás egyik pillére a digitális eszközök használata. A távolsági oktatás minden pedagógust óriási kihívás elé állított. Meg kellett találni a platformot, a módszert, amely részben helyettesítheti a tantermi oktatást. Biztos vagyok benne, hogy az elmúlt időszak elemzésével az oktatáskutatók, digitális neveléssel foglalkozó szakemberek még sokat fognak foglalkozni. A pedagógustársadalom kiválóan vette az akadályt, és áthidalta az előtte álló nehézséget a közoktatás minden területén. Látható, hogy a digitális kompetencia fejlesztése összetett feladat a pedagógushallgatók körében is. Tanszékünk a DigComp keretrendszerben felvázolt 21 részkompetencia mentén igyekszik a pedagógusjelöltek digitális kompetenciáit fejleszteni úgy, hogy rugalmasan tudjanak reagálni olyan váratlan helyzetekre, amelyek az oktatási folyamatban előfordulhatnak. Igyekszünk kialakítani bennük a tudásvágyat, pozitív attitüdöt a digitális eszközök, tartalmak megfelelő és hatékony használata iránt.

\section{Irodalom}

Carretero, S., Vuorikari, R., \& Punie, Y. (2017). DigComp 2.1: Állampolgári digitális kompetenciakeret nyolc jártassági szinttel és gyakorlati példákkal. https://www. 
kormany.hu/download/d/dc/a1000/DigComp\%2021\%20-\%20Állampolgári\%20 digitáliskompetencia-keret\%20Nyolc\%20jártassági\%20szinttel\%20és\%20 gyakorlati\%20példákkal.pdf

Csapó, B. (2002). A tudás és a kompetenciák. In Monostori, A. (Ed.), A tanulás fejlesztése (pp. 65-74). Országos Közoktatási Intézet (OKI).

Duson, J. (2016). Tanitás és tanulás elektronikus környezetben. Typotop Kft.

Eszenyiné Borbély, M. (2018). Pedagógus digitális kompetencia-körkép 1. rész. Tudományos és Müszaki Tájékoztatás, 65(12), 627-652.

Ferrari, A. (2013). DIGCOMP: A Framework for Developing and Understanding Digital Competence in Europe. European Commission.

Jorgen, F. (2017). Pedagogical Digital Competence - Between Values, Knowledge and Skills. Higher Education Studies, 7(2), 43-50. https://doi.org/10.5539/hes.v7n2p43

Kárpáti, A. \& Hunya, M. (2009). Tanárok informatikai kompetenciájának vizsgálata - az U-Teacher Projekt eredményei I. Új Pedagógiai Szemle, 59(2), 95-106.

Krumsvik, R. A. (2011). Digital competence in Norwegian teacher education and schools. Högre Utbildning, 1(1), 39-51.

Lakatosné Török, E. \& Kárpáti, A. (2009). Az informatikai kompetencia, a pedagógiai gyakorlat és az innovációs sikeresség összefüggései az európai digitális tananyagportál magyar kipróbálói csoportjában. Magyar Pedagógia, 109(3), 227-259.

Lénárd, A. (2019). A digitális környezet következményei és lehetőségei kisgyermekkorban. Iskolakultúra, 29(4-5), 99-114. https://doi.org/10.14232/ISKKULT.2019.4-5.99

Müller, A, (2016). A 21. századi magyartanár módszerei. Neteducatio.

Nagy, J. (2002). XXI. század és nevelés. Osiris Kiadó.

Nemzeti alaptanterv (2020). A Kormány 5/2020. (I. 31.) Korm. rendelete a Nemzeti alaptanterv kiadásáról, bevezetéséről és alkalmazásáról szóló 110/2012. (VI. 4.) Korm. rendelet módosításáról, Magyar Közlöny, 75(17), 290-466.

Racskó, R. (2017). Digitális átállás az oktatásban. Iskolakultúra-könyvek 52. Gondolat Kiadó. https://doi.org/10.17717/IQKONYV.Racsko.2017

Sabaliauskas, T., Bukantaite, D., \& Pukelis, K. (2006). Designing teacher information and communication technology competencies' areas. Vocational Education: Research E Reality, 12, 152-165.

Tóth-Mózer, Sz. \& Kárpáti, A. (2016). A digitális kompetencia kognitív dimenziója és összefüggésrendszere egy empirikus kutatás tükrében. Magyar Pedagógia, 116(2), 121-150. https://doi.org/10.17670/MPed.2016.2.121

Vetési, E. (2018). A tevékenység-központú pedagógia neveléstörténeti háttere. In Lénárd, A. (Ed.) Az algoritmikus gondolkodás fejlesztése padlórobotok segítségével (pp. 5-10). Stiefel Eurocart Kft. 


\section{Turzó-Sovák, N.}

\section{Development of digital competences in teacher training}

One of the challenges of the 21st century is the effective use of digital tools in the educational process. An essential condition for this is the development of digital competence. The definition of this concept has expanded in recent decades, so today we mean not only the use of digital tools, but also a system of knowledge, skills and attitudes. The European Commission has developed a digital framework called DigComp which has 21 key sub-competencies under 5 competence. This framework can increase the competitiveness of the individual in the labour market. The given sub-competencies are also relevant for training teacher in higher education. The Department of Digital Pedagogy within ELTE TÓK offers courses that prepares their students for pedagogical careers in accordance with the European standard digital competence framework.

Keywords: competence, digital competence, teacher education, competence system, competence development

Turzó-Sovák Nikolett: https://orcid.org/0000-0002-0465-2730 